Politik Indonesia: Indonesian Political Science Review 1 (1) (2016) 45-68

Politik Indonesia

Indonesian Political Science Review

http://journal.unnes.ac.id/nju/index.php/JPI

\title{
Partai Politik Islam dan Pemilihan Umum: Studi Peningkatan Dukungan Elektoral PKB dan PPP Pada Pemilu Legislatif 2014 DPR RI di Dapil DKI Jakarta
}

\author{
Donie Kadewandana Malik ${ }^{1 凶}$ \\ ${ }^{1}$ Universitas Indonesia, Indonesia
}

\section{Info Artikel}

Sejarah Artikel:

Diterima 30 Juli 2015

Disetujui 15 Desember 2015

Dipublikasi 15 Januari 2016

Keywords:

Islamic Political Party; PKB; PPP; Election

\begin{abstract}
Abstrak
Studi ini bertujuan untuk menganalisis peningkatan dukungan elektoral PKB dan PPP pada Pemilu Legislatif 2014 DPR RI di Dapil DKI Jakarta. Bila merujuk hasil Pemilu 2004 dan Pemilu 2009, kedua partai politik Islam tersebut mengalami penurunan dukungan elektoral. Namun konstelasi politik berubah pada Pemilu 2014, suara PKB dan PPP mengalami peningkatan. Kenaikan dukungan elektoral mayoritas partai-partai politik Islam di Pemilu Legislatif 2014 merupakan fenomena baru di Masa Reformasi. Sebelum Pemilu 2014 diselenggarakan, terdapat prediksi dari pengamat dan lembaga-lembaga survei yang menyatakan bahwa suara partaipartai politik Islam akan sulit mengalami kenaikan dan cenderung mengalami kemerosotan seperti pada Pemilu 2004 dan Pemilu 2009. Namun ternyata ramalan itu meleset, mayoritas kekuatan politik Islam justru mengalami kenaikan dukungan di dalam Pemilu 2014. Maka tulisan ini akan mendeskripsikan lebih lanjut mengenai faktor penyebab meningkatnya dukungan elektoral PKB dan PPP pada Pemilu Legislatif 2014 DPR RI di Dapil DKI Jakarta.
\end{abstract}

\begin{abstract}
This study aimed to analyze the increase of voice support of Islamic parties (PKB and PPP) on Legislative Election 2014 House of Representative Republic of Indonesia in DKI Jakarta Constituency. Referring to the results of Legislative Elections on 2004 and 2009, PKB and PPP votes have significant decreased. However, political constellation changed in the 2014 election, votes of PKB and PPP have increased. The increase of electoral support of the majority of political parties on the legislative elections 2014, is a new phenomenon in the Reformation Era. Before 2014 election, there were predictions of analysts and institutions survey stated that the party vote-Islamic political party will be difficult to rise and tend to decline as in the 2004 and 2009 elections. But the forecast is not proven, the majority of Islamic political power has increased in the 2014 election. Therefore, this article will describe more about the factors causing the increase in electoral support of PKB and PPP on Legislative Election 2014 House of Representative Republic of Indonesia in DKI Jakarta Constituency
\end{abstract}

(C) 2016 Universitas Negeri Semarang

\footnotetext{
Alamat korespondensi:

Universitas Indonesia, Kampus UI Depok, Kota Depok, Jawa Barat 16424, Indonesia

Email:doniemalik@gmail.com cc:donie.kadewandana@ui.ac.id
} ISSN $2477-8060$ 


\section{Pendahuluan}

Fokus utama studi ini ialah peningkatan dukungan elektoral partai politik Islam (PKB dan PPP) pada Pemilu Legislatif 2014 DPR RI di Dapil DKI Jakarta. Bila merujuk data KPU, dalam Pemilu Legislatif 2014 DPR RI di Dapil DKI Jakarta terdapat tiga partai politik Islam (PKB, PPP, PAN) yang melampaui ambang batas parlemen (parliamentary threshold) sekaligus mengalami kenaikan dukungan elektoral. ${ }^{5}$ Dari tiga partai itu, peneliti memilih dua partai yang dukungan elektoralnya paling signifikan serta mewakili tipologi partai politik Islam secara asas maupun basis massa, yaitu PPP dan PKB untuk dijadikan sebagai subjek penelitian.

Dalam Pemilu Legislatif 2014 DPR RI di Dapil DKI Jakarta, persentase elektoral PKB mengalami peningkatan dibandingkan Pemilu Legislatif 2009. Begitu juga bila dikomparasikan dengan Pemilu 2004 dan Pemilu 1999, perolehan elektoral PKB pada Pemilu 2014 masih berada pada posisi tertinggi $(4,89 \%)$. Artinya kenaikan dukungan elektoral PKB dalam Pemilu 2014 merupakan antitesa dari realitas elektoral PKB pada pemilu-pemilu sebelumnya. Sementara dukungan suara PPP juga tidak kalah meningkatnya di Pemilu 2014 (10,17\%). Perolehan persentase elektoral PPP mengalami kenaikan dibanding Pemilu 2009

\footnotetext{
${ }^{5}$ Untuk lebih lengkapnya lihat salinan Model E-1 DPR yang dilansir Biro Hukum KPU, Rekapitulasi Jumlah Perolehan Suara Sah Partai Politik Secara Nasional dalam Pemilu Anggota DPR tahun 2014.
}

dan Pemilu 2004 DPR RI di Dapil DKI Jakarta.

Dari sejumlah penelitian yang pernah dilakukan terhadap partai-partai politik Islam di pemilu pasca-Orde Baru, sepengetahuan peneliti belum pernah ada yang meneliti mengenai faktor penyebab peningkatan dukungan elektoral partai-partai politik Islam (PKB dan PPP) di Pemilu Legislatif tingkat nasional maupun Propinsi DKI Jakarta terutama dalam kurun waktu 2004-2014. Hal itu karena memang kedua partai tersebut terus mengalami penurunan dukungan dan baru mengalami kenaikan elektoral pada Pemilu Legislatif 2014. Pertanyaan yang muncul kemudian, mengapa PKB dan PPP pada Pemilu Legislatif 2014 DPR RI di Dapil DKI Jakarta mengalami peningkatan dukungan elektoral. Apa faktor-faktor yang menyebabkan hal itu terjadi?

\section{Kajian Pustaka \\ Metodologi}

Penelitian ini menggunakan metode kualitatif, sedangkan teknik analisa data menggunakan deskriptif analitis. Dalam penelitian ini digunakan dua metode teknik pengumpulan data, yaitu: sumber primer dan sekunder. Sumber primer dikumpulkan melalui teknik wawancara mendalam (indepth interview). Wawancara mendalam ini didasarkan pada sebuah panduan wawancara, pertanyaan-pertanyaan terbuka, dan penyelidikan informal yang digunakan untuk memfasilitasi diskusi tentang isu-isu yang 
diangkat. Mengacu hal tersebut akan dibuat catatan-catatan lapangan yang mendalam. Percakapan tersebut merupakan data mentah yang kemudian menjadi bahan analisis dan interpretasi dalam laporan penelitian.

Sementara sumber sekunder diperoleh dari studi kepustakaan (library research), yaitu instrumentasi penelitian dengan mengumpulkan berbagai macam literatur relevan baik itu jurnal, buku, working paper, laporan jurnalistik di media massa, dokumen resmi partai, dan hasil survei lembaga independen yang memiliki kaitan dengan permasalahan dalam penelitian ini.

Adapun langkah-langkah yang dilakukan dalam menganalisis data di lapangan yaitu: pertama, melakukan studi pendahuluan dengan meneliti kajian-kajian penelitian terdahulu yang membahas mengenai masalah partai politik Islam (PKB dan PPP) di dalam pemilu. Kedua, mengumpulkan literatur relevan sesuai dengan fokus permasalahan yang diangkat. Ketiga, melakukan wawancara mendalam terhadap para informan penelitian yang terkait dengan topik penelitian. Untuk itu, dalam penelitian ini informan yang dipilih adalah informan yang menyangkut keputusan partai dalam hal ini pengurus atau struktur pimpinan partai Islam (PKB dan PPP) yang terlibat dalam proses Pemilu Legislatif 2014. Untuk memperkaya data, wawancara dilakukan dengan beberapa intelektual dan akademisi yang menurut peneliti memiliki kepakaran dalam persoalan kepartaian dan politik Islam di Indonesia serta memahami dinamika internal PKB dan PPP. Pemilihan informan bukan semata berdasarkan subyektivitas peneliti, melainkan didasarkan pada tema dan substansi penelitian. Adapun pihak-pihak yang dijadikan informan penelitian ini adalah sebagai berikut:

1. Drs. H. Saifullah Ma'shum (Ketua Lembaga Pemenangan Pemilu (LPP) DPP PKB, Anggota DPR RI dari PKB 2004-2009, Dewan Tanfidz DPP PKB).

2. H. Hasbiallah Ilyas, S.Ag. (Ketua DPW PKB DKI Jakarta, Anggota DPRD DKI Jakarta dari PKB 20142019).

3. Dr. H.R. Achmad Dimyati Natakusumah, $\quad \mathrm{SH}, \quad \mathrm{MH}, \quad$ M.Si. (Anggota DPR RI Dapil DKI Jakarta dari PPP 2014-2019, Ketua DPP PPP, Anggota DPR RI Dapil Banten dari PPP 2009-2014, Bupati Pandeglang Banten 2000-2009).

4. H. Achmad Fauzan, SH, M.Kom.I. (Anggota DPR RI Dapil DKI Jakarta dari PPP 2014-2019).

5. H. Joko Krismiyanto, SQ. (Ketua DPW PPP DKI Jakarta 2014-2019, Ketua Lajnah Pemenangan Pemilu DPW PPP DKI Jakarta).

6. Prof. Dr. KH. Said Aqil Siradj (Ketua Pengurus Besar Nahdlatul Ulama (PBNU), anggota Tim Lima pendiri PKB). 
7. Prof. (riset) Dr. Syamsuddin Haris, M.Si. (Kepala Pusat Penelitian Politik LIPI 2008-2014, Peneliti Senior Politik LIPI).

8. Prof. Dr. Bahtiar Effendy, MA. (Guru Besar Politik Islam, Dekan FISIP UIN Jakarta).

Keempat, melakukan komparasi dengan data lain untuk menemukan lokus korelasi dan permasalahannya. Dan yang kelima, menulis hasil penelitian ini berdasarkan argumentasi analisis dari berbagai data tersebut.

Politik Islam dan Islam Politik: Sebuah Kerangka Pemikiran

Konsep "Politik Islam" dan "Islam Politik" kendati terdiri dari dua kata yang sama, yakni politik dan Islam atau Islam dan politik, tetapi masing-masing mempunyai makna yang berbeda. Kata Islam yang terdapat dalam konsep "Politik Islam" yang apabila diterjemahkan bisa diartikan sebagai "politik yang sesuai dengan ajaran Islam" atau "politik yang islami." Sedang kata Islam yang terdapat dalam konsep "Islam Politik" berfungsi sebagai "pemilik" atau "yang memiliki” yaitu ajaran tentang politik. Jadi, "Islam politik" berarti ajaran Islam tentang politik (Kholil, 2009).

Jika paradigma politik Islam menekankan pada gerakan atau kegiatan sekelompok umat Islam di bidang politik secara kultural dan substansial dengan tidak menggunakan partai berlabel Islam.
Sedangkan paradigma Islam politik adalah gerakan atau kegiatan sekelompok umat Islam di bidang politik dengan menggunakan label Islam, baik simbol, asas, ataupun atribut lainnya. Dengan kata lain, konsep yang pertama menggunakan pendekatan substansialistik, sedang konsep yang kedua menggunakan pendekatan formalistik.

Pendekatan formalistik dalam pandangan M. Syafii Anwar, menunjukkan perhatian pada orientasi yang cenderung menopang masyarakat politik yang dibayangkan (imagined Islamic polity), seperti terwujudnya suatu sistem politik Islam, munculnya partai Islam, ekspresi simbolis dan idiom-idiom politik Islam, dan sebagainya. Pendekatan ini sangat menekankan ideologisasi dan politisasi simbolisme keagamaan secara formal (Anwar, 1995).

Secara umum pendekatan formalistik ini berpandangan bahwa Islam harus menjadi dasar negara, syariah harus diterima sebagai konstitusi negara, kedaulatan politik ada di tangan Tuhan, gagasan tentang negara bangsa (nation state) bertentangan dengan konsep ummah yang tidak mengenal batas-batas politik atau kedaerahan, dan sistem politik modern diletakkan dalam posisi yang berlawanan dengan negara Islam.

Meminjam kerangka Gulalp, bahwa pendekatan formalistik ini masuk ke dalam kategori "Islam politik", yaitu Islam yang muncul atau ditampilkan sebagai kerangka ideologi politik dan menjelma dalam bentuk partai politik. Dengan demikian Islam politik 
adalah Islam yang berusaha diwujudkan dan diaktualisasikan dalam kekuasaan atau kelembagaan politik resmi, khususnya pada bidang legislatif dan eksekutif. Fenomena berdirinya partai-partai politik Islam pasca Orde Baru dapat dijelaskan dengan pendekatan Islam formalistik atau pendekatan Islam politik. ${ }^{6}$

Bila dilihat dari aspek kelembagaan, terdapat dua kategori Islam politik yang lahir pada Era Reformasi. Pertama, Islam politik yang terlembaga menjadi partai dan kedua yang non-partai, seperti ormas-ormas Islam. Karakteristik partai politik Islam kerap dilihat dari dua hal, yaitu asas dan basis massa. Dari segi asas, partai Islam dimaknai sebagai partai yang menggunakan asas Islam di dalam Anggaran Dasar/Anggaran Rumah Tangga (AD/ART), seperti PPP, PKS, dan PBB. Sedangkan partai berbasis massa Islam dimaknai sebagai partai yang memosisikan ormas-ormas Islam, seperti Nahdlatul Ulama (NU) dan Muhammadiyah sebagai basis massa partai. Partai yang masuk golongan ini antara lain PKB dan PAN. Walaupun PKB dan PAN tidak menjadikan Islam sebagai asas di AD/ART, tetapi dalam penelitian ini digolongkan sebagai partai politik Islam karena pertimbangan kedua partai tersebut secara kultural tidak bisa dilepaskan dari

${ }^{6}$ Halil Gulalp, Political Islam in Turkey: The Rise and Fall of The Rifah Party, The Muslim World, Hartford Seminary, Vol. 89, No.1, 1999. organisasi sosial keagamaan Islam, yaitu NU dan Muhammadiyah. ${ }^{7}$

$$
\text { Sementara itu, pendekatan }
$$

substansialitik dalam terminologi Din Syamsuddin diartikan sebagai pendekatan yang menekankan tuntutan manifestasi substansial nilai-nilai Islam dalam aktivitas politik, bukan sekadar manifestasinya yang formal, baik dalam ide maupun kelembagaannya. Bagi pendukung orientasi ini, yang lebih penting adalah eksistensi ajaran-ajaran Islam dalam arena politik Indonesia, dan untuk mendorong islamisasi perlu dilakukan kulturalisasi, yaitu penyiapan landasan budaya menuju terwujudnya masyarakat Indonesia modern (Syamsuddin, 1998).

\section{Temuan dan Diskusi}

Partai Politik Islam dan Pemilu Legislatif 2014

Pada pemilu yang diselenggarakan tanggal 9 April 2014, empat partai Islam dinyatakan berhasil melampaui ambang batas parlemen (parliamentary threshold) sehingga mendapatkan kursi di DPR yaitu PPP, PKS,

\footnotetext{
7 Secara historis, PKB dan PAN masing-masing didirikan oleh kader NU dan Muhammadiyah. Namun, PKB dan PAN bukan merupakan partainya NU dan Muhammadiyah, sebab kedua ormas tersebut tidak berpartai. PKB dan PAN enggan disebut sebagai Partai Islam karena secara de jure PKB dan PAN telah menyatakan diri di dalam AD/ART-nya sebagai partai yang berasaskan nasionalis, sekalipun mayoritas basis massa pemilih mereka berasal dari kalangan Islam. Sehingga, yang disebut sebagai basis massa pemilih Islam di sini yaitu individu-individu yang berasal dari kader NU dan Muhammadiyah yang masing-masing menyalurkan aspirasi politiknya melalui PKB dan PAN, walaupun itu tidak semua, tetapi jumlahnya cukup signifikan.
} 
PKB, dan PAN. Bila merujuk hasil Pemilu 2004 dan Pemilu 2009, tiga dari empat partai politik Islam itu (PKB, PAN, PPP) mengalami penurunan dukungan elektoral. Namun konstelasi politik berubah pada Pemilu 2014, tiga partai Islam tersebut mengalami peningkatan dukungan elektoral (persentase suara).

Tabel 1. Hasil Perolehan Suara Partai-Partai Politik Islam (4 besar) Pada Pemilu Legislatif (Anggota DPR) Tingkat Nasional Masa

\section{Reformasi}

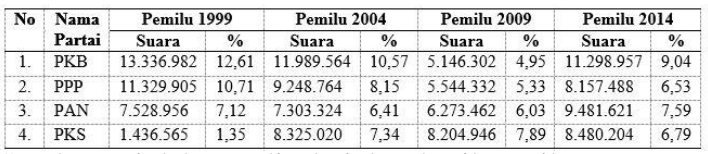
\begin{tabular}{llllllllllll} 
4. & PKS & 1.436 .565 & 1,35 & 8.325 .020 & 7,34 & 8.204 .946 & 7.89 & 8.480 .204 & 6,79 \\
\hline
\end{tabular} Sumber: Diolah penulis dari data hasil pemilu yang dilansir KPU Pusat 1999-2014.

$$
\text { Kenaikan dukungan elektoral }
$$
mayoritas partai-partai Islam di Pemilu Legislatif 2014 merupakan fenomena baru di pemilu masa Reformasi. Sebab selama pemilu legislatif masa Reformasi ketiga partai tersebut selalu mengalami kemerosotan suara. Selain itu terdapat prediksi dari para pengamat politik dan lembaga-lembaga survei yang menyatakan bahwa partai-partai Islam akan sulit mengalami peningkatan dukungan elektoral dan cenderung mengalami kemerosotan seperti pada Pemilu 2004 dan 2009. Namun ternyata ramalan itu meleset, mayoritas kekuatan politik Islam justru mengalami kenaikan dukungan.

Dari sisi partai politik Islam, mayoritas partai mengalami kenaikan dukungan suara, kecuali PKS yang menurun persentase dan kursinya. PKB sendiri merupakan partai politik Islam yang paling signifikan peningkatan dukungannya. Di pemilu 2014, PKB mengalami kenaikan hampir 5 persen, dari yang sebelumnya (Pemilu 2009) mendapat 4,95 persen menjadi 9,04 persen suara. Kursi di DPR pun meningkat dari 28 menjadi 47 kursi. Peningkatan terbesar suara PKB terjadi di Dapil Jawa Timur. Di daerah ini PKB meraih 15 kursi DPR.

Setelah lima tahun peta politik Jawa Timur dikuasai Partai Demokrat, kini di Pemilu Legislatif 2014 warnanya kembali menjadi hijau. Kemenangan kembali PKB terlihat dari hasil rekapitulasi perolehan suara partai yang dilakukan KPU. Berdasarkan data rekapitulasi suara dari KPU, khususnya di Kabupaten/Kota di Jawa Timur, PKB berhasil mendapat 3.671.911 suara $(19,61$ persen $)$ sekaligus keluar sebagai pemenang pemilu di Jawa Timur. ${ }^{8}$ Pada Pemilu Legislatif 2014 di Jawa Timur ini, dari 38 kabupaten/kota, PKB berhasil menang di 17 daerah, yakni Sidoarjo, Kota Pasuruan, Kabupaten Pasuruan, Kabupaten Probolinggo, Bondowoso, Situbondo, Jember, Kota Batu, Trenggalek, Jombang, Kabupaten Madiun, Bojonegoro, Tuban, Lamongan, Gresik, Pamekasan, dan Sumenep. ${ }^{9}$

Kemenangan PKB di Jawa Timur mengulang sukses yang pernah diraih pada pemilu 1999 dan pemilu 2004. Waktu itu,

8 Mujib Anwar, Hasil Pemilu di Jawa Timur: PKB Kuasai 17 Kabupaten-Kota dan PDIP 16, http://www.tribunnews.com/pemilu2014/2014/04/24/hasil-pemilu-di-jawa-timur-pkbkuasai-17-kabupaten-kota-dan-pdip-16, diakses pada 4 Juli 2015.

${ }^{9}$ Ibid. 
partai berlambang bola dunia yang dikelilingi sembilan bintang ini juga berhasil keluar sebagai pemenang pemilu di Jawa Timur. Namun sukses tersebut terhenti pada pemilu 2009, di mana pemenang pemilu berhasil direbut oleh Partai Demokrat.

Sementara partai politik Islam lainnya di dalam konteks nasional, seperti PPP dan PAN juga mengalami peningkatan suara, masing-masing mendapat 6,53 persen (39 kursi) dan 7,59 persen (49 kursi). Sedangkan PKS di Pemilu 2014 ini, persentase suara dan kursinya menurun. Di Pemilu 2009 PKS mendapat 7,89 persen suara dan 57 kursi. Kini di Pemilu 2014 PKS hanya mendapat 6,79 persen suara dan 40 kursi DPR. Penurunan persentase PKS ini, menurut peneliti dipengaruhi oleh faktor memburuknya citra PKS akibat tersangkutnya Presiden PKS Luthfi Hasan Ishak dalam kasus korupsi pengadaan sapi di Kementerian Pertanian.

Sementara dari tubuh partai nasionalis-sekuler di Pemilu 2014 secara nasional, mayoritas mengungguli partai-partai politik Islam. Di posisi pertama sekaligus menjadi pemenang Pemilu, yaitu PDI Perjuangan dengan perolehan suara 23.681.471 (18,95\%) dan 109 kursi DPR. Keberhasilan PDI Perjuangan menurut peneliti tidak bisa dilepaskan dari faktor Jokowi yang banyak mendapat simpati dari pemilih karena dinilai sebagai figur yang jujur dan merakyat. Selain itu, gaya kepemimpinan blusukuannya yang diadaptasi sejak menjabat walikota Solo dan Gubernur DKI Jakarta, cukup mendapat respons positif dari masyarakat luas.

Selanjutnya, partai baru yang mendapat suara yang cukup memuaskan adalah Nasdem yang meraih suara 6,72 persen dan mendapat 35 kursi. Performa baik dari Nasdem di Pemilu 2014 tak terlepas dari faktor media yang dimiliki Ketua Dewan Pembina Partai, Surya Paloh. Dengan medianya tersebut, Partai Nasdem semakin dikenal banyak kalangan sehingga elektabilitasnya pun kian meroket.

Lalu partai yang paling banyak mengalami penurunan perolehan suara dan kursi adalah Partai Demokrat. Dari sebelumnya (Pemilu 2009) mendapat 20,81 persen dan 148 kursi sekarang hanya memperoleh 10,19 persen suara dan 61 kursi. Kemerosotan Demokrat di Pemilu 2014 ini, disebabkan kader-kadernya banyak yang tersangkut korupsi dan menjadi tersangka KPK. Beberapa pengurus DPP Demokrat kini telah berada di penjara seperti: Muhammad Nazaruddin, Anas Urbaningrum, Andi Mallarangeng, dan Angelina Sondakh. Akibat penurunan ini, suara Demokrat banyak beralih ke beberapa partai lain, seperti PKB dan PAN. Kemudian partai yang banyak mengalami kenaikan suara dan kursi adalah Partai Gerindra, dari 4,46 persen suara (26 kursi) menjadi 11,81 persen (73 kursi). Kenaikan tajam suara Gerindra banyak dipengaruhi oleh faktor iklan politik yang masif dan berkesinambungan di berbagai media massa. Untuk PBB dan PKPI karena 
suaranya tidak memenuhi ambang batas parliamentary threshold 3,5 persen, maka tidak mendapatkan kursi di DPR.

Sementara itu, untuk Pemilu Legislatif 2014 DPR RI di Dapil DKI Jakarta, persentase elektoral partai-partai politik Islam mengalami peningkatan dibanding Pemilu Legislatif 2009, kecuali PKS yang menurun. Di wilayah ini ada tiga Dapil yang diperebutkan, yaitu Dapil DKI Jakarta 1 (Jakarta Timur), Dapil DKI Jakarta II (Jakarta Pusat, Jakarta Selatan, Luar Negeri), dan Dapil DKI Jakarta 3 (Jakarta Barat, Jakarta Utara, dan Kepulauan Seribu).

PKB dari yang sebelumnya hanya mendapat 1,46 persen, sekarang meningkat menjadi 4,89 persen suara. Bila dikomparasikan dengan Pemilu 2009, 2004 dan Pemilu 1999, perolehan elektoral PKB pada Pemilu 2014 DPR di Dapil DKI Jakarta masih berada pada posisi tertinggi kendati tidak ada kursi yang didapatkan. Begitu juga dengan PPP yang mengalami peningkatan. Dari sebelumnya (Pemilu 2009) mendapat 4,60 persen suara (1 kursi) menjadi 10,17 persen (3 kursi). Sedangkan PAN mirip dengan PKB, secara kursi meningkat (4,32\%) namun tidak ada kursi yang didapatkan. Dan untuk PKS sendiri adalah partai Islam satusatunya yang secara suara dan kursi menurun. Pada pemilu 2009, PKS mendapat 18,39 persen suara (4 kursi). Namun di pemilu kali ini turun menjadi 10,99 persen suara dengan meraih 3 kursi.
Tabel 2. Hasil Perolehan Suara Partai-Partai Politik Islam (4 besar) Pada Pemilu Legislatif (Anggota DPR) di Dapil DKI Jakarta Masa Reformasi

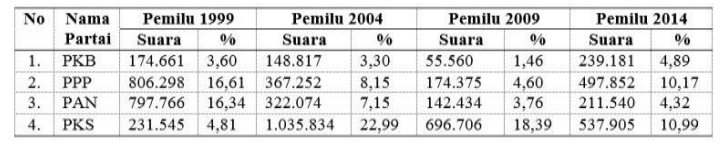
Sumber: Diolah penulis dari data hasil pemilu yang dilansir KPU Pusat dan KPU DKI Jakarta 1999-2014.

Bila mengacu perolehan suara partaipartai nasionalis-sekuler, rupanya suara partai politik Islam masih tertinggal jauh. Di Dapil DKI Jakarta sendiri yang memenangkan Pemilu 2014 adalah PDI Perjuangan dengan raihan suara 28,8 persen (6 kursi), naik dua kali lipat dibanding Pemilu 2009. Di samping PDI Perjuangan, Partai Gerindra dan Partai Golkar juga mengalami peningkatan suara dan kursi. Masing-masing memperoleh 12,48 persen (3 kursi) dan 8,8 persen (3 kursi).

\section{Performa Elektoral PKB pada Pemilu} Legislatif 2014 DPR RI di Dapil Dki Jakarta

Saat pertama kali PKB berkontestasi dalam pemilu, sambutan masyarakat pemilih begitu antusias. Hal itu terlihat dari perolehan suara PKB yang signifikan di Pemilu 1999 dengan keluar sebagai pemenang ketiga setelah PDI Perjuangan dan Golkar. PKB saat itu mengantongi suara sebesar 12,61\%. Perolehan suara tersebut sudah tergolong fantastis untuk ukuran partai baru. Sebab ratarata partai baru cenderung berada di posisi bawah atau maksimal lima besar di kala awal ikut pemilu.

Namun permulaan yang baik itu rupanya tidak dilanjutkan PKB di dua pemilu berikutnya. Perolehan suara PKB di Pemilu 
2004 dan 2009 mengalami kemerosotan, yang masing-masing mendapat 10,57 persen dan 4,95 persen. Serupa dengan DPR tingkat nasional, perolehan suara PKB di Pemilu Legislatif DPR Dapil DKI Jakarta juga terus mengalami penurunan dari 3,60 persen di tahun 1999, lalu turun di Pemilu 2004 menjadi 3,30 persen, dan puncaknya pada Pemilu 2009 yang hanya memperoleh 1,46 persen suara. Penurunan dua kali suara PKB di pemilu ini menjadi pukulan telak sekaligus pelajaran bagi PKB. Apalagi bila melihat basis sosial kuat yang dimiliki $\mathrm{PKB}$, semestinya $\mathrm{PKB}$ dapat mempertahankan perolehan suara di 1999, atau setidaknya dapat sama dengan hasil Pemilu 2004. Namun dalam realitanya PKB justru mengalami degradasi kekuatan elektoral dengan penurunan perolehan suara yang signifikan.

Melihat situasi yang kritis itu, kepemimpinan PKB pada periode 2009-2014 yang dikomandoi oleh Muhaimin Iskandar menghadapi tantangan besar untuk melakukan terobosan-terobosan baru guna meningkatkan dukungan suara PKB di dalam pemilu. Pertaruhannya adalah, jika PKB masih terus mengalami involusi elektoral di Pemilu 2014, maka bukan tidak mungkin ke depan PKB hanya tinggal nama karena tidak bisa melewati ambang batas parlemen (parliamentary threshold) 3,5 persen. Jika itu terjadi, tentu ceruk pemilih dari kalangan Nahdliyin (NU) yang selama ini menjadi basis dukungan terbesar PKB, akan pindah ke partai lain yang bukan anak kandung dari NU. Jika itu terjadi, suara warga NU akan semakin terfragmentasi dan aspirasi mereka juga semakin berat untuk diperjuangkan oleh partai-partai yang memang bukan dibidani oleh tokoh dan kalangan NU itu sendiri.

Untuk meredam kekalutan itu semua, di Pemilu 2014 ini PKB terlihat banyak melakukan terobosan-terobosan baru yang belum pernah dilakukan sebelumnya. Dari berbagai langkah yang PKB lakukan ternyata cukup efektif dalam meningkatkan perolehan suara PKB. Hasil penelusuran peneliti, peningkatan suara PKB di Dapil DKI Jakarta lebih banyak dipengaruhi oleh DPP PKB, karena dari segi pemilihan caleg DPR yang menyeleksi langsung dari DPP. Sedangkan pada ranah DPW PKB DKI Jakarta lebih fokus pada tingkatan DPRD. Walaupun demikian, ada juga caleg DPR dan DPRD yang saling bersinergi, namun itu pun jumlahnya tidak banyak.

Dari hasil analisa intensif yang dilakukan terhadap performa PKB dalam Pemilu Legislatif 2014, peneliti menemukan enam faktor yang menyebabkan meningkatnya dukungan elektoral PKB pada Pemilu Legislatif 2014 DPR di Dapil DKI Jakarta. Faktor-faktornya yaitu: soliditas partai (tidak ada konflik internal), dukungan kuat dari organisasi sosial keagamaan (NU), pemunculan figur populer, dukungan modal finansial, kepemimpinan politik Muhaimin Iskandar, serta pelembagaan dan pengorganisasian pemenangan pemilu. 
Soliditas Partai (Tidak Ada Konflik Internal)

Soliditas partai merupakan salah satu faktor penting bagi partai politik untuk menciptakan kohesivitas dan stabilitas organisasi. Jika di dalam suatu partai hanya sedikit diterpa oleh faksionalisasi, maka roda dan mesin partai akan lebih mudah dijalankan, sehingga bisa mencapai tujuan bersama. Namun sebaliknya, bila di dalam partai kerap muncul faksi-faksi yang berujung pada konflik, maka yang terjadi adalah kemacetan di dalam mencapai tujuan bersama.

Faksionalisasi di dalam tubuh partai politik kerap terjadi karena lemahnya kontrol pimpinan (manajer) partai dan lemahnya konsolidasi partai. Artinya bila di dalam partai, pengurus dan kadernya solid, maka faksionalisasi akan sulit muncul (Lewis, 2000). Keutuhan partai dapat dilihat dari ada tidaknya pembelahan dalam partai (faksionalisme internal). Adanya dialog dalam partai memang prasyarat penting bagi tumbuhnya wacana yang sehat, namun tumbuhnya perdebatan bahkan lahirnya faksionalisme dalam partai akan dapat merugikan pengembangan partai politik ke depan. Kendati partai politik merupakan kumpulan aktor yang memiliki kepentingan dan kebutuhan berbeda tetapi perbedaan itu bukan lantas dapat dijadikan pemecah soliditas partai.

Semenjak kelahirannya pada 23 Juli 1998, PKB bisa dikatakan tak pernah lepas dari konflik. Dualisme kepemimpinan Dewan Syuro dan Dewan Tanfidz selalu menyulut perseteruan yang tajam. Hal itu terlihat misalnya ketika Ketua Dewan Syuro DPP PKB Gus Dur sebagai tokoh sentral berpolemik dengan beberapa orang yang dianggap tidak sejalan dengannya. Misalnya kasus pemecatan Matori Abdul Djalil, pemecatan Alwi Shihab, pemberhentian Khoirul Anam, reposisi Saifullah Yusuf, konflik yang terjadi dengan kubu Muhaimin Iskandar hingga ketegangan antara Muhaimin Iskandar dengan Yenny Wahid pasca wafatnya Gus Dur. Hasil konflik internal itu membuat banyak elite PKB yang akhirnya keluar dari struktural PKB dan membuat partai sempalan seperti PKNU.

Imbas dari dinamika konflik itu, khususnya konflik antara Gus Dur dan Muhaimin Iskandar pada 2008, menyebabkan PKB sempat berada pada situasi yang kurang menguntungkan karena kondisi internal dan eksternal partai yang tidak stabil. Secara internal, kekuatan partai terbelah akibat konflik yang berkepanjangan. Implikasinya dirasakan dalam persiapan menghadapi Pemilu 2009. Energi yang seharusnya dialokasikan untuk merencanakan strategi pemilu malah terkuras untuk kepentingan mengelola dan menyelesaikan konflik. Dari segi eksternal, suasana kompetisi politik yang berlangsung pada saat itu sangat ketat, baik antarpartai maupun antarcaleg, baik caleg sesama partai maupun caleg yang berbeda partai. ${ }^{10}$ Dampak dari itu semua, membuat

\footnotetext{
10 Saifullah Ma'shum, dkk., Selamatkan Demokrasi Menangkan PKB: Pedoman Pemenangan Pemilu 2014
} 
performa elektoral partai berlambang bola dunia ini mengalami kemerosotan tajam pada Pemilu 2009.

Berkaca dari pengalaman Pemilu 2009, maka dalam menghadapi Pemilu 2014, DPP PKB melakukan berbagai langkah strategis untuk menciptakan soliditas dan stabilitas partai. ${ }^{11}$ Dari langkah-langkah intensif itu akhirnya mampu menciptakan situsasi internal partai yang lebih kondusif dibanding kondisi menjelang Pemilu 2009. Tidak ada lagi kepengurusan ganda, baik di level pusat maupun di bawahnya. Sehingga konsolidasi program pemenangan pemilu bisa berjalan sesuai dengan yang diharapkan.

Konsolidasi politik dan organisasi pun dapat dilakukan dengan cepat. Kader-kader dan tokoh-tokoh pendahulu seperti Alwi Shihab, Khofifah Indar Parawansa, Mahfud MD dan KH Ma'ruf Amin, dirangkul kembali untuk membesarkan PKB. Hubungan dengan NU yang sempat ranggang disinergikan kembali. Ketua Umum PBNU KH Said Aqil Siradj pun kerap kali ikut serta dalam menyapa basis-basis NU di banyak daerah. ${ }^{12}$ Selain itu, PKB juga melakukan konsolidasi total melalui seluruh jajaran pengurus, baik dari tingkat pusat sampai ke tingkat akar rumput (DPP, DPW, DPC, DPAC). ${ }^{13}$

11 Partai Kebangkitan Bangsa, Jakarta: Lembaga Pemenangan Pemilu (LPP) DPP PKB, 2013, hlm. 22.

12 Hanif Dakhiri, Aklamasi Cak Imin, http://politik.kompasiana.com/2014/09/06/aklamasi-cakimin-685904.html, diakses pada 10 April 2015.

13 Nahdliyin "Pulang Kandang", PKB Melejit, http://nasional.kompas.com/read/2014/04/10/0652009/N
Karena kian solidnya PKB menjelang

Pemilu 2014, berdampak pada meningkatnya kekuatan elektoral partai. Sehingga mengantarkan PKB pada perolehan suara yang signifikan bila dibandingkan Pemilu 2009. Dari situ, bisa dilihat bahwa basis Nahdliyin di akar rumput, baik tingkat nasional maupun di DKI Jakarta akan tetap setia mendukung PKB jika struktur PKB solid. Namun sebaliknya, jika PKB terusmenerus dirundung konflik, warga Nahdliyin yang mempunyai jiwa kohesivitas yang tinggi, akan memilih partai lain yang dekat dengan NU, selain PKB.

\section{Dukungan Kuat dari Organisasi Sosial Keagamaan $(N U)$}

Secara historis, PKB merupakan partai politik yang lahir dan dibidani oleh tokoh-tokoh PBNU. Hadirnya PKB di kancah perpolitikan nasional, merupakan pengulangan sejarah bagi NU ketika menjadi partai politik. Namun demikian, lahirnya PKB memiliki atmosfer yang berbeda dengan partai NU di masa lalu. Ketika PKB didirikan, NU telah menyatakan diri kembali ke khitah 1926 dan tidak akan berpolitik praktis. Sehingga pengurus NU tidak diperkenankan untuk merangkap jabatan di PKB.

Selain menjadi anak kandung NU, PKB mewarisi berbagai tradisi yang dimiliki oleh NU seperti Dewan Tanfidz dan Dewan Syuro. Di samping itu, ikatan kultural dan

ahdliyin.Pulang.Kandang.PKB.Melejit), diakses pada 20 April 2015. 
historis dengan NU sangat kental di PKB. Warga NU yang merupakan golongan masyarakat tradisional di Indonesia dan sebagian besar Jawa memiliki karakteristik yang unik, yaitu kental dengan sifat pedesaan dan kekeluargaan yang kuat. Karakteristik yang unik ini merupakan sebuah kekuatan bagi PKB. Bila dihitung dari jumlah anggota NU yang 80 juta orang (angka moderat tentang jumlah warga NU secara nasional), maka PKB merupakan satu-satunya partai politik yang memiliki kekuatan basis massa terbesar di Indonesia, meskipun massa NU relatif cair. Atas basis massa yang besar itu, maka dalam konteks Pemilu 2014, PKB memberi insentif kuota bagi kalangan Nahdliyin untuk mengisi pos pencalegan PKB. ${ }^{14}$ Komposisinya sesuai tertuang di dalam konstitusi partai yaitu: 50 persen caleg dari kader dan pengurus PKB, 25 persen dari pengurus atau badan otonom NU, dan 25 persen dari kalangan profesional. Serangkaian nilai atau norma-norma informal yang dimiliki bersama antara NU dan PKB inilah, yang menurut Fukuyama dapat dijadikan ikatan dalam hubungan sosial yang terbangun. ${ }^{15}$

Secara teoritis, basis massa PKB yang berasal dari kalangan NU ini disebut juga sebagai modal sosial PKB. Menurut Pierre Bourdieu, modal sosial (social capital) adalah

14 Lihat Saifullah Ma'shum, dkk., Produk Hukum Pemenangan Pemilu, Jakarta: Sekjen DPP PKB, 2012, hlm. 3.

15 Francis Fukuyama, Trust: Kebajikan Sosial dan Penciptaan Kemakmuran, Ruslani (terj.), Yogyakarta: Penerbit Qalam: 2002, hlm. xii. sumber daya aktual sekaligus potensial yang dimiliki seseorang atau organisasi, yang berasal dari jaringan sosial yang terlembagakan serta berlangsung terus menerus dalam bentuk pengakuan dan perkenalan timbal balik. Keanggotaan dalam kelompok sosial tersebut memberikan kepada anggotanya berbagai bentuk dukungan kolektif. Ia menambahkan pula bahwa modal sosial mengacu pada keuntungan dan kesempatan yang didapatkan seseorang di dalam masyarakat melalui keanggotaanya (Bourdieu, 1986). Dalam konteks ini, warga Nahdliyin merupakan anggota dari kelompok sosial keagamaan yang memberikan dukungannya kepada PKB. Karena sudah terbentuk jaringan yang kuat, maka keduanya akan terus bersimbiosis di dalam setiap aktivitasnya, terutama di dalam ranah politik elektoral.

Menjelang Pemilu 2014, hubungan NU dan PKB kian sinergis dan harmonis. Hal itu tercermin dari kedekatan hubungan antara tokoh-tokoh PKB dan PBNU. Menurut Ketua Lembaga Pemenangan Pemilu (LPP) DPP PKB Saifullah Ma'shum, hubungan NU-PKB dapat ditinjau dari berbagai aspek, yaitu historis, ideologis, kultural, emosional, fungsional, dan struktural. Dari kesemua itu, hanya hubungan struktural yang tidak boleh tercipta secara politis karena di dalam AD/ART nya, NU tidak boleh terlibat politik praktis. Tapi di luar itu, seperti hubungan historis, ideologis, kultural, emosional, 
fungsional dilakukan jejaring yang luas oleh PKB. ${ }^{16}$

Dengan berbagai aspek itulah, maka NU-PKB bersimbiosis di Pemilu 2014. Dari dokumen resmi partai PKB yang peneliti telusuri, terlihat memang dalam Pemilu 2014 ini dukungan dari NU ke PKB, baik itu tingkat nasional mapun di DKI Jakarta lebih kuat bila dibandingkan Pemilu 2009. Tokohtokoh NU secara terbuka memberi dukungan penuh pada PKB di berbagai acara dan kesempatan. Kerjasama secara intensif dilakukan dengan Muslimat, Fatayat, dan badan otonom NU lainnya. Ketua PBNU KH. Said Aqil Siradj pun terlihat rajin menghadiri acara yang diselenggarakan oleh DPP PKB. Bahkan KH. Said Aqil juga tak sungkansungkan untuk tampil dalam iklan kampanye PKB.

\section{Pemunculan Figur Populer}

Untuk menarik simpati dari pemilih, partai-partai politik Islam maupun partai nasionalis-sekuler tak luput dalam menampilkan figur yang populer dan memiliki pengaruh di kalangan masyarakat luas. Bone dan Ranney mengatakan bahwa pemilih akan memilih calon atau kandidat berdasarkan kualitas instrumental atau kualitas simbolik yang bersangkutan. Kualitas instrumental adalah keyakinan pemilih terhadap kemampuan kandidat dalam

${ }^{16}$ Wawancara dengan Drs. H. Saifullah Ma'shum, Ketua Lembaga Pemenangan Pemilu (LPP) DPP PKB, Anggota DPR RI dari PKB (2004-2009), Dewan Tanfidz DPP PKB, Kamis, 7 Mei 2015, di Kantor Institut Kewarganegaraan Indonesia (IKI), Jakarta. mewujudkan kebaikan bagi masyarakat yang akan dipimpin. Sementara kualitas simbolik mengacu pada kepribadian dan tampilan dari calon atau kandidat (Bone dan Ranney, 1981).

Menjelang Pemilu Legislatif 2014, baik itu di tingkat nasional maupun di DKI Jakarta, untuk mendapat dukungan yang masif dari pemilih, PKB gencar menampilkan tokoh populer. Dari pengamatan peneliti ada dua polarisasi pemunculan figur-figur populer oleh PKB. Pertama dari internal dan kedua dari eksternal partai. Dari figur internal yang muncul adalah tokoh-tokoh dari PKB dan NU itu sendiri, seperti pengurus $\mathrm{PKB}$, mantan pengurus $\mathrm{PKB}$, dan tokoh NU. Misalnya Mahfud MD (Mantan pengurus PKB, Mantan Menteri dan Anggota DPR dari PKB, serta bakal Calon Presiden dari PKB), KH. Said Agil Siradj (Anggota Tim Lima pendiri PKB), Alwi Shihab (Mantan Ketua Umum PKB), Khofifah Indar Parawansa (Mantan Pengurus DPP PKB, Mantan Menteri dari PKB), KH. A. Hasyim Muzadi (Mantan Ketua PBNU), KH. Dr. Ma'ruf Amin (Mantan pengurus PBNU).

Sedangkan figur eksternal yang dimuncukan oleh DPP PKB sekaligus diusung menjadi bakal calon presiden adalah raja dangdut Rhoma Irama. Bila dibandingkan dengan tokoh-tokoh dari PKB atau NU, popularitas Rhoma Irama lebih di atas mereka. Sebab Rhoma Irama bagi masyarakat bukan sosok yang asing. Kiprahnya di belantika musik tanah air sudah dibangun sejak puluhan tahun. Lagu-lagu ciptaannya 
pun hingga kini masih akrab di telinga masyarakat. Sejak Rhoma Irama digadanggadang oleh PKB, namanya pun kian meroket. Dari jajak pendapat atau polling yang diadakan oleh lembaga survei atau lembaga penelitian, Rhoma kerap disejajarkan dengan tokoh-tokoh nasional capres lainnya seperti Jokowi, Prabowo, Megawati, Aburizal Bakrie, Hatta Rajasa, dan lain sebagainya.

\section{Lantas seberapa besar Rhoma Effect?}

Untuk mengetahui hal itu, kita bisa berkaca dari jajak pendapat yang dilakukan oleh lembaga-lembaga survei. Dari berbagai survei yang pernah diadakan, ternyata elektabilitas Rhoma Irama paling besar hanya mencapai $3,5 \% .{ }^{17}$ Apa artinya? Dari hasil itu menunjukkan bahwa Rhoma Effect tetap ada, namun pengaruhnya tidak signifikan dan merata di seluruh Indonesia. Hanya di beberapa daerah saja faktor Rhoma berpengaruh. Misalnya di Aceh, Kalimantan

17 Survei capres dilakukan oleh Pusat Penelitian Politik (P2P) LIPI pada 10-31 Mei 2013 di 31 provinsi di Indonesia dengan melibatkan 1.799 responden melalui wawancara tatap muka, dengan margin error 2,31 persen dan tingkat kepercayaan 95 persen. Hasil survei menunjukkan elektabilitas Joko Widodo berada di urutan pertama dengan persentase 22,6 persen. Lalu diikuti oleh Capres Gerindra, Prabowo Subianto 14,2 persen, Capres Golkar Aburizal Bakrie 9,4 persen. Kemudian, disusul Megawati Soekarnoputri dari PDI Perjuangan 9,3 persen, Jusuf Kalla 4,2 persen, Rhoma Irama 3,5 persen, Capres Hanura Wiranto 3,4 persen, Mahfud MD 1,9 persen, Hatta Rajasa 1,2 persen, Sri Sultan HB X 1,2 persen, dan Surya Paloh 1,2 persen. Sementara itu, untuk tokoh yang paling populer atau dikenal oleh pemilih urutan pertama ditempati oleh Megawati Soekarnoputri 93,2 persen, Jusuf Kalla 90,9 persen, Rhoma Irama 89,2 persen, Joko Widodo 85,1 persen, Prabowo Subianto 82,1 persen. Kemudian, Wiranto 77,8 persen, Aburizal Bakrie 76,9 persen, Ani Yudhoyono 73,5 persen, Hatta Rajasa 66,8 persen, Sri Sultan Hamengkubuwono X 55,6 persen, Agum Gumelar 54,6 persen, Surya Paloh 53,4 persen, Sutiyoso 50,3 persen, Yusril Ihza Mahendra 49,9 persen, dan Hidayat Nurwahid 47,5 persen.
Selatan, Jawa Barat, dan NTT. Pertanyaannya kemudian bagaimana dalam konteks DKI Jakarta? Apakah faktor Rhoma Irama berpengaruh bagi peningkatan suara $\mathrm{PKB}$ ? Ternyata bila melihat kondisi masyarakat DKI Jakarta yang majemuk dan kosmopolit, efek Rhoma Irama masih berpengaruh namun tidak sebesar di empat daerah yang disebutkan Ma'shum.

\section{Dukungan Modal Finansial}

Sumber daya finansial bagi partai politik mempunyai peran penting karena hampir setiap ruang gerak politik membutuhkan pendanaan. Secara umum, partai memerlukan dana besar untuk memenuhi kebutuhan campaign finance dan party finance. Party finance adalah keuangan partai politik yang diperoleh dan digunakan untuk menjalankan kegiatan partai di luar masa kampanye, termasuk menggerakan infrastruktur dan jaringan partai. Adapun campaign finance merupakan keuangan partai politik yang diperoleh dan digunakan selama masa kampanye (Muhtadi, 2013).

Dalam konteks itu, masuknya bos Lion Grup Rusdi Kirana pada Januari 2014 ke PKB dengan menjadi Wakil Ketua Umum, membuat modal finansial partai ini semakin kuat. Seperti diketahui, Rusdi Kirana merupakan pengusaha maskapai penerbangan yang tergolong sukses. Di industri kedirgantaraan Indonesia, nama Rusdi Kirana cukup populer. Maskapai penerbangan Lion Air yang mempunyai semboyan "we make 
people fly" selama dikomandoi Rusdi mampu menguasai sebagain besar rute penerbangan di nusantara.

Sebulan setelah bergabung di PKB, pada Februari 2014, Rusdi Kirana membuat program kerjasama wirausaha antara NU-Lion Grup. Dalam program itu, Rusdi menggelontorkan dana ratusan ribu dollar untuk pemberdayaan ekonomi anggota NU. Rusdi mengaku bahwa kolaborasi NU-Lion Grup adalah bagian dari rencananya yang lebih luas untuk memberdayakan dan mengembangkan aktivitas ekonomi kader NU. ${ }^{18}$ Bergabungnya Rusdi Kirana membuat PKB kian segar dalam menghadapi Pemilu 2014.

Jika pada pemilu sebelumnya, penyelenggaraan kampanye PKB kerap dilakukan secara sederhana, namun dengan masuknya Rusdi Kirana, membuat PKB mampu menyelenggarakan kampanye yang lebih megah sebagaimana partai besar lainnya. Misalnya, PKB melakukan kampanye melalui medium iklan di berbagai televisi dengan frekuensi tayang yang signifikan. Selain itu, PKB menggelontorkan dana yang besar untuk menyewa konsultan politik Saiful Mujani Research and Consulting, sebagai konsultan kampanyenya. ${ }^{19}$ Menurut Ma'shum, penggunaan konsultan politik dan kampanye yang baru pertama kali ini dilakukan, adalah

${ }^{18}$ Greg Fealy, The Puzzle of Rusdi Kirana and Islamic Politics, http://insidestory.org.au/the-puzzle-of-rusdikirana-and-islamic-politics, diakses pada 11 Februari 2015.

${ }^{19}$ Ibid. upaya untuk mengoptimalkan potensi yang dimiliki PKB. ${ }^{20}$

Kemampuan PKB yang mampu memobilisasi dana dari Rusdi Kirana membuat jumlah dana kampanye PKB secara nasional pada tahun ini meningkat dibanding tahun sebelumnya. Ketika peneliti menanyakan hal ini kepada Ketua LPP DPP PKB Saifullah Ma'shum ia mengatakan dengan ragu-ragu sekitar Rp. 800 miliar. Namun, secara cepat ia meralatnya. Ia menyarankan peneliti untuk melihat hasil pelaporan dana partai di KPU. Peneliti kemudian menelusuri laporan dana partaipartai yang disampaikan ke KPU. ${ }^{21}$ Dari laporan tersebut menunjukan bahwa dana kampanye PKB yang berasal kas internal partai sebesar Rp. 45.000.000.000. Sementara dana kampanye yang berasal dari sumbangan para caleg PKB berjumlah Rp. 100.966.440.940. Bila ditotal, berarti PKB memiliki dana kampanye nasional sebesar Rp. 145.966.440.940. Dalam konteks Pemilu Legislatif 2014 DPR di Dapil DKI Jakarta, DPW PKB DKI Jakarta secara tidak langsung banyak terbantu oleh dukungan finansial dan logistik Rusdi Kirana karena kampanye yang dilakukan oleh DPP PKB di DKI Jakarta bertambah megah dan semarak. Sehingga hal itu berefek pada dukungan pemilih di dalam pemilu di tingkat DKI Jakarta.

\footnotetext{
20 Wawancara dengan Drs. H. Saifullah Ma'shum, Op.Cit.

${ }^{21}$ Untuk lebih lengkapnya lihat laporan dana kampanye partai-partai politik peserta Pemilu 2014, melalui www.kpu.go.id.
} 
Kepemimpinan Politik Muhaimin Iskandar

Aspek kepemimpinan merupakan salah satu faktor penting di dalam menjalankan roda dan mesin partai politik. Bila kepemimpinan seorang ketua partai baik maka akan menghasilkan output yang baik juga di dalam perkembangan partainya. Dari beberapa pengakuan pengurus PKB di pusat maupun di tingkat DKI Jakarta, serta analisa pakar politik menilai bahwa kepemimpinan politik Muhaimin Iskandar sangat baik terutama dalam hal kemampuan memenej partai. Ia mampu menyatukan seluruh sumber daya partai dan membangun sistem yang solid.

Dalam analisa peneliti, kepiawaian manuver Muhaimin Iskandar dalam Pemilu Legislatif 2014 dapat dilihat dari beberapa hal. Pertama, Muhaimin Iskandar berhasil memperkokoh struktur partai, SDM, dan ideologi partai. Dengan begitu, maka dapat tercipta kohesifitas yang simbiotik di internal partai. Kedua, Muhaimin berhasil menjaga harmonisasi hubungan antara PKB dengan NU baik di pusat, wilayah, kabupaten bahkan sampai ranting. Serta dapat merangkul dan menjaga hubungan baik dengan Said Aqil Siradj, Mahfud MD, Alwi Shihab, Ma'ruf Amin, Khofifah Indar Parawansa, Hasyim Muzadi, Jusuf Kalla (Mustasyar/Penasehat PBNU), dan tokoh-tokoh NU lainnya. Ketiga, kemampuan Muhaimin dalam menakapitalisasi ketokohan Rhoma Irama untuk melakukan kampanye. Berdasarkan survei popularitas Rhoma Irama di kalangan masyarakat Indonesia cukup tinggi. Sehingga dengan Muhaimin mengahadirkan Rhoma, maka secara langsung dapat mempengaruhi elektabilitas PKB. Keempat, kemampuan Muhaimin dalam menggaet bos Lion Air Rusdi Kirana ke PKB yang merupakan salah satu penyumbang dana terbesar bagi PKB. Sehingga itu dapat menunjang logistik kegiatan kampanye PKB di dalam pemilu.

\section{Pelembagaan dan Pengorganisasian Pemenangan Pemilu \\ Dalam menghadapi Pemilu Legislatif} 2014, persiapan yang dilakukan DPP PKB terlihat lebih matang dibandingkan pemilupemilu sebelumnya. Bila dalam pemilu sebelumnya PKB mempersiapkan organorgan dan program-program hanya dalam hitungan 6 sampai 12 bulan. Tapi kini berbeda. Sejak dari dua setengah tahun sebelumnya, PKB sudah membentuk Lembaga Pemenangan Pemilu (LPP). ${ }^{22}$ Dengan masa yang relatif panjang tersebut, sehingga PKB lebih punya banyak waktu dalam melakukan perencanaan, persiapan, konsolidasi dan pelembagaan program pemenangan pemilu.

Dengan pelembagaan dan pengorganisasian LPP yang berada di tingkat pusat maupun di daerah (termasuk di DKI Jakarta) tersebut, setidaknya mempermudah PKB untuk berkontestasi di dalam kontestasi elektoral. Dalam pandangan peneliti,

22 Wawancara dengan Drs. H. Saifullah Ma'shum, Op.Cit. 
pelembagaan dan pengorganisasian LPP DPP PKB ini merupakan sebuah modal politik yang efektif untuk mewujudkan kepentingannya di dalam meraih kekuasaan politik. Dengan bekal pelembagaan dan pengorganisasian LPP yang matang dan sistemtis tersebut, mempermudah PKB dalam menjalankan dan mengefektifkan mesin partai di Pemilu 2014.

Performa Elektoral PPP pada Pemilu Legislatif 2014 DPR RI di Dapil DKI Jakarta

PPP sejak didirikan pada 5 Januari 1973 hingga 2014, telah mengikuti sembilan kali pemilu. Sementara dalam pemilu masa Reformasi, PPP telah mengikuti empat kali pemilu. Dari Pemilu 1999 hingga 2009, perolehan suara PPP terus mengalami penurunan. Di pemilu pertama masa reformasi (Pemilu 1999), PPP mendapat suara nasional yang signifikan yaitu sebesar 11.329.905 $(10,71 \%)$. Namun perolehannya itu tidak dapat dipertahankan di pemilu berikutnya. Pada Pemilu 2004 suara PPP menurun menjadi ( 8,15 persen), lalu di 2009 merosot lagi menjadi 5,33 persen.

Serupa dengan di lingkup nasional, di tingkat Pemilu Legislatif DPR Dapil DKI Jakarta PPP mengalami kemunduran elektoral. Pada Pemilu 1999, suara PPP cukup besar yaitu 16,61 persen. Namun kemudian menurun tajam di Pemilu 2004 menjadi 8,15 persen. Dan kian terjun bebas pada Pemilu 2009, yang hanya meraih 4,60 persen.
Setelah peneliti melakukan wawancara mendalam dan menelusuri berbagai bahan literatur, peneliti menemukan tiga penyebab kenaikan suara PPP dalam Pemilu Legislatif 2014 DPR Dapil DKI, yaitu pertama, kuatnya dukungan dari organisasi sosial-keagamaan dan kultural (basis massa NU DKI Jakarta dan massa kultural Betawi). Kedua, modal finansial caleg yang besar. Dan ketiga karena faktor kampanye langsung/tatap muka dari caleg.

\section{Dukungan Organisasi Sosial Keagamaan dan} Kultural (Basis Massa NU DKI Jakarta dan Massa Kultural Betawi) - Organisasi Sosial Keagamaan (Basis Massa NU DKI Jakarta)

PPP merupakan partai politik Islam tertua dan memiliki jaringan paling luas di antara partai politik Islam lainnya. Seperti halnya dengan PKB yang mempunyai basis sosial dari kalangan Nahdliyin, PPP pun mempunyai basis massa yang serupa dengan PKB ditambah dari ceruk massa Islam lainnya, seperti Muslimin Indonesia, Perti, dan Sarikat Islam. Sedang di DKI Jakarta basis massa PPP juga datang dari massa kultural betawi.

Basis sosial yang dimiliki PPP ini ada karena merupakan hasil dari jaringan pendukung PPP yang memang sejak lama sudah menjadi unsur internal di dalamnya. Jaringan inilah yang kemudian diistilahkan sebagai modal sosial. Robert Putnam mendefiniskan modal sosial sebagai institusi sosial yang melibatkan jaringan (networks), 
norma-norma (norms), dan kepercayaan sosial (social trust) yang mendorong kepada sebuah kolaborasi sosial (koordinasi dan kooperasi) untuk kepentingan bersama (Putnam, 1993).

Secara historikalnya, PPP dibentuk dari kebijakan Pemerintah Orde Baru yang melakukan fusi partai. Partai-partai bercorak Islam digabung ke dalam PPP dan partaipartai bercorak nasionalis-kristen ke PDI. NU yang merupakan partai Islam bersama tiga unsur pendukung lainnya (Parmusi, PSII, Perti) melebur menjadi PPP.

Menurut Ketua DPW PPP DKI Jakarta Joko Krismiyanto, basis Nahdliyin kuat karena secara historis NU di Jakarta adalah NU yang Masyumi. Jadi ketika NU masih menjadi unsur pendukung partai Masyumi, di Jakarta mayoritas berasal dari kalangan Masyumi. ${ }^{23}$ Namun kemudian ketika Presiden Soekarno membubarkan Masyumi pada tahun 1960 karena dianggap terlibat dalam pemberontakan PRRI, NU pun ikut lepas dari Masyumi, dan berdiri menjadi partai yang mandiri. Dari konteks itulah kemudian NU di Jakarta masih cenderung bercirikan Masyumi yang modernis. Selain itu, pada Pemilu 1955, partai pemenang pemilu di DKI Jakarta adalah Masyumi, yang di dalamnya NU menjadi pendukung mayoritas. Dalam Pemilu tahun 1977 pun PPP menjadi pemenang pemilu di DKI Jakarta.

${ }^{23}$ Wawancara dengan H. Joko Krismiyanto, SQ, Ketua DPW PPP DKI Jakarta (2014-2019), Ketua Lajnah Pemenangan Pemilu DPW PPP DKI Jakarta, Selasa, 21 April 2015, di Kantor DPP PPP, Jakarta.

\section{Basis Massa Kultural Betawi}

Di samping pendukung PPP yang berasal dari basis massa NU DKI Jakarta yang masih bercirikan Masyumi, pendukung kuat PPP lainnya berasal dari massa kultural Betawi. Menurut data yang dilansir dari Lembaga Survei Indonesia (LSI) pada tahun 2012, kekuatan basis massa kultural Betawi di DKI Jakarta cukup besar, yakni sekitar 30\%. Komposisi etnik Betawi di DKI Jakarta tersebut menjadi kekuatan sosial yang dapat mempengaruhi perilaku politik pemilih di DKI Jakarta. ${ }^{24}$ Peran massa kultural Betawi dalam mengangkat masalah isu etnis dan isu daerah guna memenangkan calonnya masih berpengaruh dalam konteks pemilu di DKI Jakarta. Clifford Geertz sebagaimana dikutip Arbi Sanit, berpandangan bahwa agama, keturunan, bahasa, ras, adat dan ikatan kedaerah merupakan faktor-faktor yang mengikat masyarakat dalam suatu kesatuan sosial (Sanit, 1985).

Peneliti politik LIPI yang pernah meneliti dan membuat buku tentang PPP dan Politik Orde Baru, Syamsuddin Haris mengatakan bahwa basis pendukung PPP di Jakarta tidak murni dari kalangan Nahdliyin, tetapi juga dipengaruhi oleh massa kultural Betawi. Ia menambahkan bahwa memang ada perbedaan antara Nahdliyin di DKI Jakarta dengan di Jawa Timur maupun Jawa Tengah.

"Dalam konteks DKI Jakarta memang berbeda, sebab basis massa

\footnotetext{
${ }^{24}$ Lembaga Survei Indonesia (LSI) dan Majalah Tempo, Temuan Survei: Pilkada DKI Jakarta, Protes Kelas Menengah, Op.Cit.
} 
PPP di Jakarta itu bukan murni kaum Nahdliyin, tapi lebih pada massa kultural betawi, walaupun sebagian besar massa kultural betawi itu pun Nahdliyin juga. Sebab Nahdliyin di Jatim dan Jateng itu kan memang spesifik. Secara kultural memang berbeda dengan Nahdliyin di DKI Jakarta. Saya kira perbedaannya terletak pada lingkungannya. Kalau di Jawa Tengah dan Jawa Timur lingkungan Nahdliyin itu dibentuk oleh pondok pesantren. Nah, lingkungan Nahdliyin di Jakarta itu bukan pondok, tapi lebih pada sekolahsekolah madrasah kebanyakan. ${ }^{, 25}$

Hampir mirip dengan pandangan di atas, Syaiful Ma'shum menjelaskan bahwa massa kultural Betawi itulah yang mempunyai kesamaan pandangan keagamaan dengan PPP, sehingga di Jakarta PPP bisa lebih unggul dari PKB.

"Di DKI, ulama atau kiai (Betawi), lebih banyak ke PPP ya. Betawi itu lebih cenderung ekslusif gagasan keagamaannya. Nah, anda tahu PKB lebih progresif keislamannya. Misalnya ketika ada kasus Ahmadiyah atau yang lainnya, mereka (PPP) kan cenderung tidak terlalu respect. Dan gerakan-gerakan Islam keras, kayak FPI, itu PPP kan memiliki kesamaan. Nah rupanya Islam Betawi itu pandangannya masih puritan. Sehingga orientasi keagamaan PKB dianggap terlalu terbuka dan liberal. Islam puritan yang dikembangkan oleh PPP itu yang menarik

25 Wawancara dengan Prof. (riset) Dr. Syamsuddin Haris, M.Si., Kepala Pusat Penelitian Politik LIPI (20082014), Peneliti Senior Politik LIPI, Selasa, 5 Mei 2015, di Kantor Pusat Penelitian Politik LIPI, Jakarta.

dikembangkan oleh kiai-kiai
Betawi." 26

Sejalan dengan itu, dukungan kuat massa kultural Betawi tidak bisa lepaskan dari tokoh-tokoh PPP yang memang banyak berasal dari DKI Jakarta atau disebut sebagai putra asli Betawi. Misalnya seperti Suryadarma Ali, Djan Faridz, Abraham Lunggana (Haji Lulung), dan tokoh-tokoh PPP lainnya. Beberapa dari mereka tercatat bergabung di dalam organisasi kedaerahan seperti Badan Musyawarah Masyarakat Betawi (Bamus Betawi).

Di dalam pemilu, partai politik maupun caleg memerlukan modal finansial untuk memenuhi kebutuhan kampanye. Dalam perspektif ekonomi, modal ekonomi/finansial bisa berupa investasi yang diberikan seseorang kepada pihak lain, kemudian dipertukarkan dengan keuntungan berupa barang atau jasa politik. Dalam terminologi Pierre Bourdieu, modal ekonomi/finansial diartikan sebagai sumber daya yang segera dan langsung dikonversi menjadi uang dan dapat dilembagakan dalam bentuk hak milik. ${ }^{27}$ Sementara peneliti sendiri mendefiniskan modal ekonomi dalam konteks politik sebagai dukungan finansial berupa dana politik yang bersumber dari pribadi maupun para donatur.

Dalam konteks Pemilu Legislatif di DKI Jakarta ternyata juga tidak luput dari masalah-masalah di atas. Berdasarkan

\footnotetext{
26 Wawancara dengan Drs. H. Saifullah Ma'shum, Op.Cit.

27 Pierre Pierre Bourdieu, "The Forms of Capital", Op.Cit., hlm. 47-51.
} 
pernyataan dari caleg DPR dan DPRD DKI Jakarta yang peneliti wawancarai, hampir semuanya mengatakan bahwa Pemilu DPR maupun DPRD di DKI, tak luput dari masalah finansial. Uang bukan lagi sekadar faktor pendukung atau sekunder namun sudah menjelma menjadi faktor penentu untuk memenangkan seseorang kandidat atau caleg di dalam pemilu. ${ }^{28}$

Untuk diketahui, ada tiga orang caleg DPR Dapil DKI Jakarta dari PPP yang lolos menjadi anggota DPR. Yaitu Achmad Dimyati Natakusumah (68.353 suara), Achmad Fauzan Harun (50.323 suara), dan Okky Asokawati (35.727 suara). Achmad Dimyati merupakan incumbent DPR Dapil Banten dan mantan Bupati Pandeglang dua periode. Achmad Fauzan mantan Kepala Kanwil Kemenag DKI Jakarta. Dan Okki Asokawati adalah mantan model dan incumbent DPR Dapil DKI Jakarta. Ketiganya menurut Ketua DPW PPP DKI Jakarta bukan pengusaha. Namun setelah peneliti telusuri, mereka ternyata semua mempunyai usaha, namun yang menjalankan orang lain. Mereka juga mampu menjaring teman-teman dari kalangan pengusaha untuk membantunya dalam pemilu.

Peneliti juga menelusuri pelaporan dana kampanye PPP yang dilaporkan ke KPU, terutama untuk DPR Dapil DKI Jakarta. Dan

\footnotetext{
${ }^{28}$ Hasil kesimpulan wawancara dengan Hasbiallah Ilyas, (Ketua DPW PKB DKI Jakarta), Joko Krismiyanto, SQ (Ketua DPW PPP DKI Jakarta), Achmad Dimyati Natakusumah, SH (Anggota DPR RI Dapil DKI Jakarta dari PPP), dan Achmad Fauzan (Anggota DPR RI Dapil DKI Jakarta dari PPP).
}

memang benar ketiga caleg yang lolos menjadi anggota DPR di atas mempunyai dana yang besar, hal itu dilihat dari jumlah sumbangan yang diberikan kepada partai. Ketiganya menyumbang dalam jumlah ratusan juta rupiah. Untuk Achmad Fauzan Harun sumbangan yang diberikan kepada PPP berjumlah Rp. 609.000.000. Sementara untuk Achmad Dimyati Natakusumah sumbangan yang diberikan ke partai Rp. 195.650.000, dan Okky Asokawati menyumbang sebesar Rp. 127.450.000. ${ }^{29}$ Total dana rata-rata per caleg bila peneliti taksir sekitar 5 miliar. Bahkan tim sukses dari Achmad Fauzan, Muhammad Taufik ketika peneliti wawancarai, mengatakan bahwa dana yang dikeluarkan oleh bosnya itu mencapai 10 miliar lebih. ${ }^{30}$

Mahalnya ongkos berdemokrasi dalam pemilu, sebenarnya sudah mulai tampak dari proses penjaringan caleg-caleg. Misalnya untuk caleg dari PPP DKI Jakarta, sebelum mendaftar sebagai caleg ditanyakan terlebih dahulu perihal modal finansial yang dipunyai. Joko Krismiyanto, Ketua DPW PPP DKI Jakarta, yang pada Pemilu 2014 menjabat sebagai Ketua Lajnah Pemenangan Pemilu DKI Jakarta mengatakan bahwa memang ada perihal kesanggupan modal finansial ketika proses seleksi para caleg. Ia juga mengakui bahwa pemilih sekarang, termasuk pemilih di DKI Jakarta cenderung

\footnotetext{
${ }^{29}$ Untuk lebih lengkapnya lihat laporan dana kampanye partai-partai politik peserta Pemilu 2014, melalui www.kpu.go.id.

30 Wawancara dengan Muhammad Taufik, tim sukses dari Achmad Fauzan, pada 23 April 2015 di Komplek DPR RI Kalibata, Jakarta Selatan.
} 
pragmatis. Ia mencontohkan misalnya ketika hendak ada kegiatan di masyarakat, segelintir kelompok-kelompok tertentu maupun perorangan meminta agar bisa dibantu dalam urusan logistiknya. Belum lagi ditambah adanya proposal-proposal sumbangan yang setiap bulannya berjumlah puluhan. Sehingga karena banyaknya beban yang mendera anggota dewan itu, maka mau tidak mau mereka akhirnya harus mencari solusi untuk merespons keinginan orang-orang itu. ${ }^{31}$

\section{Kampanye Langsung/Tatap Muka}

Kampanye merupakan bagian dari serangkaian aktivitas politik di dalam proses penyelenggaraan pemilu. Dalam arti ini, kampanye politik adalah periode yang diberikan oleh panitia pemilu kepada semua kontestan, baik partai politik atau perorangan, untuk memaparkan program-program kerja dan memengaruhi opini publik sekaligus memobilisasi masyarakat agar memberikan suara kepada mereka sewaktu pencoblosan (Lilleker dan Negrine, 2006).

Dalam wawancara mendalam antara peneliti dengan beberapa caleg dan ketua PPP, tergambarkan bahwa kenaikan suara PPP satu faktornya adalah kampanye. Kampanye yang dilakukan PPP dapat menarik simpati pemilih. Hal itu seperti yang diutarakan Suryadharma Ali bahwa kampanye yang dilakukan calegcaleg PPP tidak melalui media iklan televisi seperti partai-partai besar lainnya. Selain keterbatasan dana, mereka juga percaya

\footnotetext{
${ }^{31}$ Wawancara dengan H. Joko Krismiyanto, SQ, Op.Cit.
}

bahwa kampanye yang dilakukan secara langsung ke masyarakat lebih efektif dibanding melalui media. ${ }^{32}$

Di samping itu, caleg-caleg PPP juga berkampanye melalui pertemuan dengan tokoh-tokoh panutan secara langsung. Hal itu terlihat dari pertemuan dan silaturahmi langsung PPP dengan ulama di berbagai daerah. Kampanye PPP yang langsung turun ke masyarakat juga dilakukan untuk menggaet pemilih pemula. Dengan strategi tatap muka, caleg dari PPP dapat lebih mudah menyampaikan dan memperkenalkan PPP kepada pemilih pemula. Mulai dari asas, lambang, fungsi dan peran dari PPP. Bagi PPP silaturahmi jauh lebih efektif daripada baliho dan iklan.

Untuk menambah jumlah suara partai yang akan berimbas pada perolehan suara caleg, maka ada beberapa caleg DPR dari PPP yang melakukan sinergi kampanye dengan caleg DPRD DKI Jakarta. Misalnya tandem kampanye yang dilakukan oleh caleg DPR Dapil 1 (Jakarta Timur) Achmad Fauzan, yang melakukan sinergi kampanye dengan caleg PPP untuk DPRD DKI Jakarta, yaitu Belly Bilalussalam, Matnoor Tindoan, dan Helmi Zakaria. Dari hasil tandem itu, Achmad Fauzan beserta Belly Bilalussalam dan Matnoor Tindoan lolos menjadi anggota dewan. Dan hanya Helmi Zakaria yang tidak terpilih. Dari kolaborasi antar caleg ini terlihat bahwa ada pengaruhnya di dalam perolehan

32 Slamet Riyadi, Strategi PPP Bisa Raih Pemilih di Pileg 2014, Harian Seputar Indonesia (Sindo), 14 April 2014. 
suara PPP dan suara caleg. Sehingga membuat perolehan suara PPP, baik pada tingkat DPR maupun DPRD meningkat di Pemilu 2014.

\section{Kesimpulan}

Meningkatnya dukungan elektoral partai-partai politik Islam di Pemilu Legislatif 2014, seperti PKB dan PPP, menunjukkan bahwa partai-partai politik Islam juga mempunyai peluang yang sama dengan partaipartai lainnya yang tidak berbasis agama untuk menaikkan suara di dalam arena politik pemilu. Jadi, partai berlabel agama atau nasionalis, ataupun yang lainnya tidak berpengaruh signifikan terhadap performa di pemilu. Melainkan yang lebih menentukan terhadap kenaikan dukungan elektoral partaipartai di dalam pemilu adalah multifaktor seperti kinerja/performa, program, maupun tokoh-tokoh dari partai politik itu sendiri. Partai berbasis agama atau nasionalis jika tidak berperforma baik maka tidak akan mendapatkan dukungan. Namun sebaliknya, partai berbasis agama atau partai nasionalis, jika berperforma baik, maka akan mendapatkan dukungan dari pemilih.

Sejalan dengan itu, ada beberapa tantangan ke depan yang harus direspons oleh partai-partai politik di Indonesia, khususnya bagi partai-partai politik Islam agar terus eksis di kancah perpolitikan tanah air. Pertama, terkait dengan kemampuan partai-partai politik Islam dalam mengaktualisasikan ideologi Islam di dalam kehidupan berbangsa dan bernegara, sehingga dapat memberikan dampak positif bagi perubahan bangsa ke arah yang lebih baik. Kedua, dalam hal kepemimpinan politik. Artinya, sejauh mana partai-partai politik Islam, bisa memiliki pemimpin-pemimpin yang visioner dan berkualitas. Ketiga, terkait dengan kemampuan pengemasan (branding) partaipartai politik Islam di era yang semakin kompetitif ini supaya bisa tetap eksis dan dilirik oleh para pemilih.

\section{Daftar Pustaka}

Anwar, M. S. I. (1995). Pemikiran dan aksi Islam Indonesia: sebuah kajian politik tentang cendekiawan Muslim Orde Baru. Paramadina.

Anwar, Mujib, Hasil Pemilu di Jawa Timur: PKB Kuasai 17 Kabupaten-Kota dan PDIP 16, http://www.tribunnews.com/pemilu2014/2014/04/24/hasil-pemilu-dijawa-timur-pkb-kuasai-17-kabupatenkota-dan-pdip-16, diakses pada 4 Juli 2015.

Biro Hukum KPU (2014), Rekapitulasi Jumlah Perolehan Suara Sah Partai Politik Secara Nasional dalam Pemilu Anggota DPR tahun 2014.

Bourdieu, P. (2011). The forms of capital.(1986). Cultural theory: An anthology, 81-93.

Bone, H. A., \& Ranney, A. (1981). Politics and voters. McGraw-Hill Companies.

Dakhiri, Hanif, Aklamasi Cak Imin, http://politik.kompasiana.com/2014/0 
9/06/

aklamasi-cak-imin-

685904.html, diakses pada 10 April 2015.

Fealy, G. (2015). The Puzzle of Rusdi Kirana and Islamic Politics.

Firmanzah (2012). Marketing Politik. Yayasan Pustaka Obor Indonesia.

Fukuyama, F. (2002). Trust: Kebajikan Sosial dan Penciptaan Kemakmuran. Yogyakarta: Penerbit Qalam.

Gulalp, H. (1999). Political Islam in Turkey: the rise and fall of the Refah Party. The Muslim World, 89(1), 22.

Kholil, M. (2009). Dinamika politik Islam Golkar di era Orde baru. Gaya Media Pratama.

Lembaga Survei Indonesia (LSI) dan Majalah Tempo, Temuan Survei: Pilkada DKI Jakarta, Protes Kelas Menengah, 2012

Lewis, P. (2002). Political parties in postcommunist Eastern Europe. Routledge.

Ma'shum, Saifullah, dkk. (2013). Selamatkan Demokrasi Menangkan PKB: Pedoman Pemenangan Pemilu 2014 Partai Kebangkitan Bangsa. Lembaga Pemenangan Pemilu (LPP) DPP PKB. Ma'shum, Saifullah, dkk. (2012). Produk Hukum Pemenangan Pemilu, Jakarta: Sekjen DPP PKB.

Muhtadi, B. (2013). Perang bintang, 2014: konstelasi dan prediksi pemilu dan pilpres. S. Priyandari (Ed.).
Nahdliyin "Pulang Kandang", PKB Melejit, http://nasional.kompas.com/read/2014 /04/10/0652009/Nahdliyin.Pulang.Ka ndang.PKB.Melejit), diakses pada 20 April 2015.

Putnam, R. D., Leonardi, R., \& Nanetti, R. Y. (1994). Making democracy work: Civic traditions in modern Italy. Princeton university press.

Politik, P. P. (2013). LIPI, Hasil Survei Capres 2014.

Riyadi, S. (2014). Strategi PPP Bisa Raih Pemilih di Pileg 2014, Harian Seputar Indonesia (Sindo), 14 April 2014.

Sanit, A. (1985). Swadaya Politik Masyarakat: Telaah tentang Keterlibatan Organisasi Masyarakat, Jakarta: CV.

Syamsuddin, M. D., \& Abd. Rohim Ghazali. (2001). Islam dan Politik Era Orde Baru. Logos Wacana Ilmu.

Wawancara dengan Drs. H. Saifullah Ma'shum, Ketua Lembaga Pemenangan Pemilu (LPP) DPP PKB, Anggota DPR RI dari PKB (20042009), Dewan Tanfidz DPP PKB, Kamis, 7 Mei 2015, di Kantor Institut Kewarganegaraan Indonesia (IKI), Jakarta.

Wawancara dengan H. Hasbiallah Ilyas, S.Ag., Ketua DPW PKB DKI Jakarta, Anggota DPRD DKI Jakarta dari PKB (2014-2019), Rabu, 22 April 2015, di Gedung DPRD DKI Jakarta. Wawancara dengan H. Joko Krismiyanto, SQ, Ketua DPW PPP DKI Jakarta (2014- 
2019), Ketua Lajnah Pemenangan

Pemilu DPW PPP DKI Jakarta,

Selasa, 21 April 2015, di Kantor DPP

PPP, Jakarta.

Wawancara dengan Dr. H.R. Achmad

Dimyati Natakusumah, $\mathrm{SH}, \mathrm{MH}$,

M.Si., Anggota DPR RI Dapil DKI

Jakarta dari PPP (2014-2019),

Anggota DPR RI Dapil Banten dari PPP (2009-2014), Bupati Pandeglang

Banten (2000-2009), Selasa, 21 April

2015, di Gedung Nusantara, DPR/MPR RI, Jakarta.

Wawancara dengan H. Achmad Fauzan, SH,

M.Kom.I., Anggota DPR RI Dapil DKI Jakarta dari PPP (2014-2019), Kepala Kantor Wilayah (Kanwil) Kementerian Agama DKI Jakarta (2003-2010), (wawancara

pendahuluan dan dilanjutkan dengan wawancara tertulis), Selasa, 21 April 2015, di Gedung DPR/MPR RI, Jakarta.

Wawancara dengan Prof. Dr. KH. Said Aqil

Siradj (Ketua Pengurus Besar

Nahdlatul Ulama (PBNU), anggota

Tim Lima pendiri PKB).

Wawancara dengan Prof. (riset) Dr.

Syamsuddin Haris, M.Si., Kepala
Pusat Penelitian Politik LIPI (20082014), Peneliti Senior Politik LIPI, Selasa, 5 Mei 2015, di Kantor Pusat Penelitian Politik LIPI, Jakarta.

Wawancara dengan Prof. Dr. Bahtiar Effendy, MA., Guru Besar Politik Islam, Dekan FISIP UIN Jakarta, Senin, 11 Mei 2015, di Kantor FISIP UIN, Jakarta. 